\title{
Thermal Behavior of Hydrated Iron Sulfate in Various Atmospheres
}

\author{
Ndue Kanari ${ }^{1, *}$, , Nour-Eddine Menad ${ }^{2}$, Etleva Ostrosi ${ }^{3}$, Seit Shallari ${ }^{4}$, Frederic Diot ${ }^{1}$, \\ Eric Allain ${ }^{1}$ and Jacques Yvon ${ }^{1}$ \\ 1 GeoRessources Laboratory, UMR 7359 CNRS, CREGU, Université de Lorraine, 2, rue du doyen Roubault, \\ BP 10162, 54505 Vandoeuvre-lès-Nancy, France; frederic.diot@univ-lorraine.fr (F.D.); \\ ericgallain@gmail.com (E.A.); jacques.yvon@univ-lorraine.fr (J.Y.) \\ 2 BRGM, 3 av. C. Guillemin, BP 36009, CEDEX 2, 45060 Orléans, France; N.Menad@brgm.fr \\ 3 Ville de Montréal, Direction de l'Environnement, Division de la Planification et du Suivi Environnemental, \\ 801, rue Brennan, Montréal, QC H3C 0G4, Canada; etlevao@yahoo.com \\ 4 Faculty of Agriculture and Environment, Agriculture University of Tirana, 1029 Tirana, Albania; \\ seitshallari@gmail.com \\ * Correspondence: ndue.kanari@univ-lorraine.fr; Tel.: +33-372-744-530
}

Received: 19 November 2018; Accepted: 13 December 2018; Published: 19 December 2018

\begin{abstract}
Iron sulfate, in particular $\mathrm{FeSO}_{4} \cdot 7 \mathrm{H}_{2} \mathrm{O}$, is derived from titanium dioxide production and the steel pickling process. Regarding $\mathrm{TiO}_{2}$ manufacturing, the amount of the resultant $\mathrm{FeSO}_{4} \cdot 7 \mathrm{H}_{2} \mathrm{O}$ can be as high as 6 tons per ton of produced $\mathrm{TiO}_{2}$, leading to a huge amount of ferrous sulfate heptahydrate, which is considered an environmental and economic concern for the titanium dioxide industry in European countries. The present paper focuses on the thermal treatment of ferrous sulfate (heptahydrate and monohydrate) samples under different conditions. Nonisothermal thermogravimetric (TG) analysis was used to study the behavior of iron sulfate samples at temperatures of up to $1000{ }^{\circ} \mathrm{C}$ in $\mathrm{Cl}_{2}+\mathrm{O}_{2}, \mathrm{O}_{2}$, and $\mathrm{N}_{2}$ atmospheres. Results showed that the dehydration of iron sulfate heptahydrate in nitrogen started at room temperature and resulted in iron sulfate tetrahydrate $\left(\mathrm{FeSO}_{4} \cdot 4 \mathrm{H}_{2} \mathrm{O}\right)$. The ferrous sulfate monohydrate $\left(\mathrm{FeSO}_{4} \cdot \mathrm{H}_{2} \mathrm{O}\right)$ was formed at temperatures close to $150{ }^{\circ} \mathrm{C}$, while the anhydrous ferrous sulfate $\left(\mathrm{FeSO}_{4}\right)$ was obtained when the samples were heated in nitrogen at over $225^{\circ} \mathrm{C}$. The kinetic features of $\mathrm{FeSO}_{4}$ decomposition into $\mathrm{Fe}_{2} \mathrm{O}_{3}$ were revealed under isothermal conditions at temperatures ranging from 500 to $575{ }^{\circ} \mathrm{C}$. The decomposition of iron sulfate was characterized by an apparent activation energy of around $250 \mathrm{~kJ} / \mathrm{mol}$, indicating a significant temperature effect on the decomposition process. The obtained powder iron oxide could be directed to the agglomeration unit of iron and the steelmaking process.
\end{abstract}

Keywords: iron sulfate; TG analysis; thermal treatment; iron oxide; kinetics; activation energy

\section{Introduction}

Titanium oxide $\left(\mathrm{TiO}_{2}\right)$ is manufactured from materials such as ilmenite, rutile, anatase, and slags using sulfate or chloride processes. The simplified schemes for the industrial processes that are currently used are presented in Figure 1 [1]. Ilmenite and titanium slags are the raw materials used for $\mathrm{TiO}_{2}$ manufacturing through the sulfate process. The ilmenite is digested in sulfuric acid, generating a solution that contains titanyl sulfate $\left(\mathrm{TiOSO}_{4}\right)$ and iron sulfate. The solution is treated with scrap iron to reduce the ferric ions into a ferrous state to avoid the precipitation of ferric hydroxide. The ferrous sulfate then crystallizes into $\mathrm{FeSO}_{4} \cdot 7 \mathrm{H}_{2} \mathrm{O}$ (melanterite) and is separated from the liquor. Additional steps (see Figure 1) are necessary to obtain the $\mathrm{TiO}_{2}$ base pigment. Depending on the quality of the raw materials used in the $\mathrm{TiO}_{2}$ production, the amount of iron sulfate produced can reach up to 6 tons 
of $\mathrm{FeSO}_{4} \cdot 7 \mathrm{H}_{2} \mathrm{O}$ per ton of produced $\mathrm{TiO}_{2}$ when ilmenite is used as the raw material. The sulfate route, which is mainly used in the production of $\mathrm{TiO}_{2}$ in European countries, generates a huge amount of wasted ferrous sulfate heptahydrate. On the contrary, North American countries produce $\mathrm{TiO}_{2}$ through the chlorine route, the main steps of which are also shown in Figure 1.

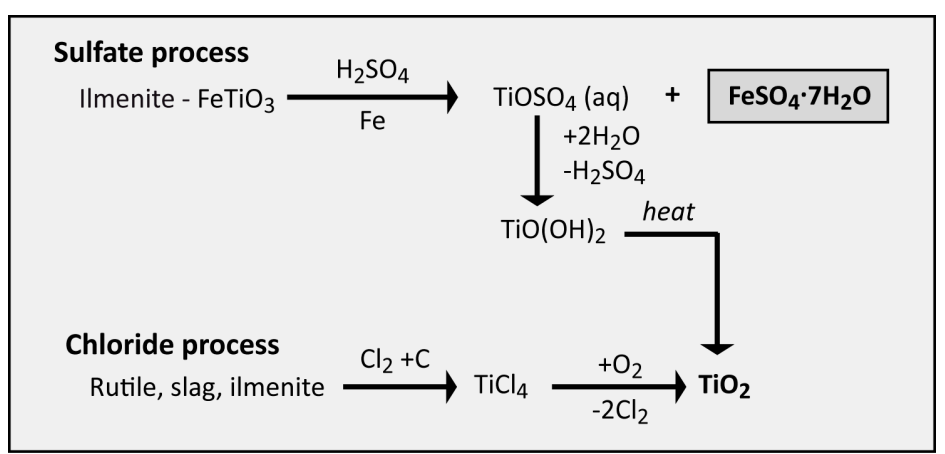

Figure 1. Schematic representation of the main steps in titanium oxide manufacturing using sulfate and chloride processes, adapted from Reference [1].

An extensive overview of the titanium metallurgical processes was recently conducted in Reference [2]. This report compares the main characteristics of the classical and emerging processes for $\mathrm{TiO}_{2}$ manufacturing from economic and environmental viewpoints. As mentioned in earlier works [3,4], one drawback of the sulfate process is the amount of iron sulfate heptahydrate and the spent acid generated during $\mathrm{TiO}_{2}$ production. Only a small part of the iron sulfate is reused, and the remaining part must be disposed of as waste. It must be noted that the amount of $\mathrm{FeSO}_{4} \cdot 7 \mathrm{H}_{2} \mathrm{O}$ generated from the surface treatment of steel is decreasing due to the use of hydrochloric acid $(\mathrm{HCl})$ instead of sulfuric acid $\left(\mathrm{H}_{2} \mathrm{SO}_{4}\right)$.

Several investigations previously conducted in our laboratory were focused on the use of industrial iron sulfate for the synthesis of alkali ferrates [3,5,6]. The potassium ferrate synthesis $\left(\mathrm{K}_{2} \mathrm{FeO}_{4}\right)$ from spent steel pickling liquid was also reported by Wei et al. [7]. A recent work applied the reductive decomposition reaction of iron sulfate with pyrite into $\mathrm{Fe}_{3} \mathrm{O}_{4}$ at a relatively low temperature [4].

In this context, the present work dealt with the dehydration and the decomposition of various iron sulfate samples in oxidizing and neutral atmospheres. Thermogravimetric (TG) analysis was used as an appropriate method to continuously follow the reaction kinetics in the decomposition of $\mathrm{FeSO}_{4}$ into iron oxide under isothermal conditions. The iron oxide obtained can be used as a raw material in the ironmaking sectors. Many recent reports are available on the reduction of iron-oxide-bearing materials from various known agents [8-16].

\section{Materials and Methods}

Several samples of the iron sulfate heptahydrate generated from industrial operators were collected, the physicochemical characterization of which has been previously given in Reference [3]. For this investigation, two samples of iron sulfate were selected. The first sample-iron sulfate monohydrate- was provided by an industrial operator and was named the IND sample. The second sample- $\mathrm{LAB}$ sample - was obtained through the two-step dehydration process of analytical-grade iron sulfate heptahydrate $\left(\mathrm{FeSO}_{4} \cdot 7 \mathrm{H}_{2} \mathrm{O}\right)$ in a laboratory oven. The heating of the $\mathrm{FeSO}_{4} \cdot 7 \mathrm{H}_{2} \mathrm{O}$ at about $60-70{ }^{\circ} \mathrm{C}$ led to the loss of $3 \mathrm{~mol}$ of water, resulting in the formation of $\mathrm{FeSO}_{4} \cdot 4 \mathrm{H}_{2} \mathrm{O}$. An increase in the temperature to about $150{ }^{\circ} \mathrm{C}$ provoked the dehydration of the iron sulfate tetrahydrate into $\mathrm{FeSO}_{4} \cdot \mathrm{H}_{2} \mathrm{O}$. However, in the presence of air, the oxidation of $\mathrm{Fe}(\mathrm{II})$ into $\mathrm{Fe}(\mathrm{III})$ may occur. Both the IND and LAB samples were subjected to a variety of analyses to determine their composition.

The total iron and Fe(II) contents of the samples were determined using chemical analysis. After sample digestion, the Fe(II) was determined using potassium dichromate titration. Table 1 gives 
the average values of iron in both the samples. The IND sample contained about $31 \% \mathrm{Fe}$, and the whole iron was in a divalent state. X-Ray diffraction (XRD) analysis only showed the presence of $\mathrm{Fe}^{\mathrm{II}} \mathrm{SO}_{4} \cdot \mathrm{H}_{2} \mathrm{O}$ in the crystallized phase. The total iron content of the LAB sample was $32.8 \%$ in which $14.8 \%$ was in a divalent state and $18.0 \%$ was in a trivalent state. In other words, in the $100 \% \mathrm{Fe}_{\text {total }} \mathrm{LAB}$ sample, about $45 \%$ was Fe(II) and about $55 \%$ was Fe(III). Concerning the results of XRD (see Table 1 ), they revealed the presence of $\mathrm{Fe}^{\mathrm{II}} \mathrm{SO}_{4} \cdot \mathrm{H}_{2} \mathrm{O}$ and $\mathrm{Fe}^{\mathrm{III}} \mathrm{SO}_{4} \cdot \mathrm{OH}$ in the $\mathrm{LAB}$ sample. This confirmed that the dehydration of $\mathrm{FeSO}_{4} \cdot 4 \mathrm{H}_{2} \mathrm{O}$ into $\mathrm{FeSO}_{4} \cdot \mathrm{H}_{2} \mathrm{O}$ and partial oxidation of $\mathrm{Fe}(\mathrm{II})$ to $\mathrm{Fe}(\mathrm{III})$ occurred by $150{ }^{\circ} \mathrm{C}$.

Table 1. Results of chemical and XRD analysis of two iron sulfate samples.

\begin{tabular}{ccccc}
\hline \multirow{2}{*}{ Sample } & \multicolumn{3}{c}{ Chemical Analysis (\%) } & XRD \\
\cline { 2 - 4 } & $\mathbf{F e}_{\text {total }}$ & $\mathbf{F e}(\mathrm{II})$ & $\mathbf{F e}(\mathrm{III})$ & \\
\hline IND & 30.9 & 30.9 & trace & $\mathrm{Fe}^{\mathrm{II}} \mathrm{SO}_{4} \cdot \mathrm{H}_{2} \mathrm{O}$ \\
LAB & 32.8 & 14.8 & $18.0^{1}$ & $\mathrm{Fe}^{\mathrm{II}} \mathrm{SO}_{4} \cdot \mathrm{H}_{2} \mathrm{O}$ and $\mathrm{Fe}^{\mathrm{III}} \mathrm{SO}_{4} \cdot \mathrm{OH}$ \\
\hline \multicolumn{5}{c}{ By difference. }
\end{tabular}

Experimental tests of thermogravimetric analysis were performed using a CAHN 1000 microbalance capable of resisting corrosive atmospheres to check the thermal behavior of $\mathrm{FeSO}_{4} \cdot 7 \mathrm{H}_{2} \mathrm{O}$ under different atmospheres $\left(\mathrm{Cl}_{2}+\mathrm{O}_{2}, \mathrm{Cl}_{2}, \mathrm{O}_{2}\right.$, and $\left.\mathrm{N}_{2}\right)$. Furthermore, a TG $2171 \mathrm{Cahn}$ balance was used to study the dehydration/decomposition kinetics of iron sulfate samples under $\mathrm{N}_{2}$ by simultaneous TG and differential thermal (DT) measurements. Solid reaction products were examined by X-ray diffraction, scanning electron microscopy, and Mössbauer spectroscopy.

\section{Results}

\subsection{Nonisothermal TG Analysis of $\mathrm{FeSO}_{4} \cdot 7 \mathrm{H}_{2} \mathrm{O}$ under Different Atmospheres}

The thermal behavior of a FeSO $4 \cdot 4 \mathrm{H}_{2} \mathrm{O}$ sample in various gaseous atmospheres $\left(\mathrm{Cl}_{2}+\mathrm{O}_{2}, \mathrm{O}_{2}\right.$, and $\mathrm{N}_{2}$ ) was investigated by TG analysis utilizing nonisothermal conditions [3]. The results are drawn in Figure 2 as the evolution of the percent mass loss (\% ML) of the sample versus temperature up to $300{ }^{\circ} \mathrm{C}$. The calculated limits corresponding to different hydrated states of ferrous sulfate are also shown in Figure 2. Results of XRD and Mössbauer analyses [1] showed that $\mathrm{FeSO}_{4} \cdot 4 \mathrm{H}_{2} \mathrm{O}, \mathrm{FeSO}_{4} \cdot \mathrm{H}_{2} \mathrm{O}$, and $\mathrm{FeSO}_{4}$ are the main crystallized phases in the solid product obtained at $75{ }^{\circ} \mathrm{C}, 150{ }^{\circ} \mathrm{C}$ and $300{ }^{\circ} \mathrm{C}$, respectively, during the treatment of iron sulfate heptahydrate sample under nitrogen atmosphere. Conversely, the treatment of the sample under oxidizing atmosphere $\left(\mathrm{Cl}_{2}+\mathrm{O}_{2}, \mathrm{O}_{2}\right)$ led to the transformation of $\mathrm{Fe}(\mathrm{II})$ into $\mathrm{Fe}(\mathrm{III})$, and the product obtained at $300^{\circ} \mathrm{C}$ was mainly composed of $\mathrm{FeSO}_{4} \cdot \mathrm{OH}$.

As revealed by Mössbauer analysis, the product resulting from the treatment of $\mathrm{FeSO}_{4} \cdot 7 \mathrm{H}_{2} \mathrm{O}$ in $\mathrm{N}_{2}$ at $150{ }^{\circ} \mathrm{C}$ was composed of $\mathrm{Fe}(\mathrm{II})$ in totality, while the product generated by the treatment in $\mathrm{Cl}_{2}+\mathrm{O}_{2}$ contained iron, mostly in a three-valent state. To observe the reactivity of iron sulfate toward $\mathrm{O}_{2}$ and $\mathrm{Cl}_{2}+\mathrm{O}_{2}$, TG tests were performed at temperatures up to $100{ }^{\circ} \mathrm{C}$, and the corresponding data is plotted in Figure 3. As can be seen, the curves for both oxidizing gas mixtures have roughly similar shapes for temperatures up to $675^{\circ} \mathrm{C}$. This observation suggests that chlorine reacted with the sample only after the decomposition of iron sulfate into ferric oxide (hematite), producing ferric chloride $\left(\mathrm{FeCl}_{3}\right)$ as a final reaction product [3]. The kinetics of the reaction of $\mathrm{Fe}_{2} \mathrm{O}_{3}$ with $\mathrm{Cl}_{2}$ and $\mathrm{Cl}_{2}+\mathrm{O}_{2}$ were further discussed in earlier articles [17,18].

The treatment of $\mathrm{FeSO}_{4} \cdot 7 \mathrm{H}_{2} \mathrm{O}$ in nitrogen at different heating rates was followed by DT analysis, and a data summary is given in Table 2. These results, combined with those of TG analysis and $\mathrm{XRD}$ analysis, show that the sequence of sample transformation was the following: $\mathrm{FeSO}_{4} \cdot 7 \mathrm{H}_{2} \mathrm{O} \rightarrow \mathrm{FeSO}_{4} \cdot 4 \mathrm{H}_{2} \mathrm{O} \rightarrow \mathrm{FeSO}_{4} \cdot \mathrm{H}_{2} \mathrm{O} \rightarrow \mathrm{FeSO}_{4} \rightarrow \mathrm{Fe}_{2} \mathrm{O}_{3}$. 


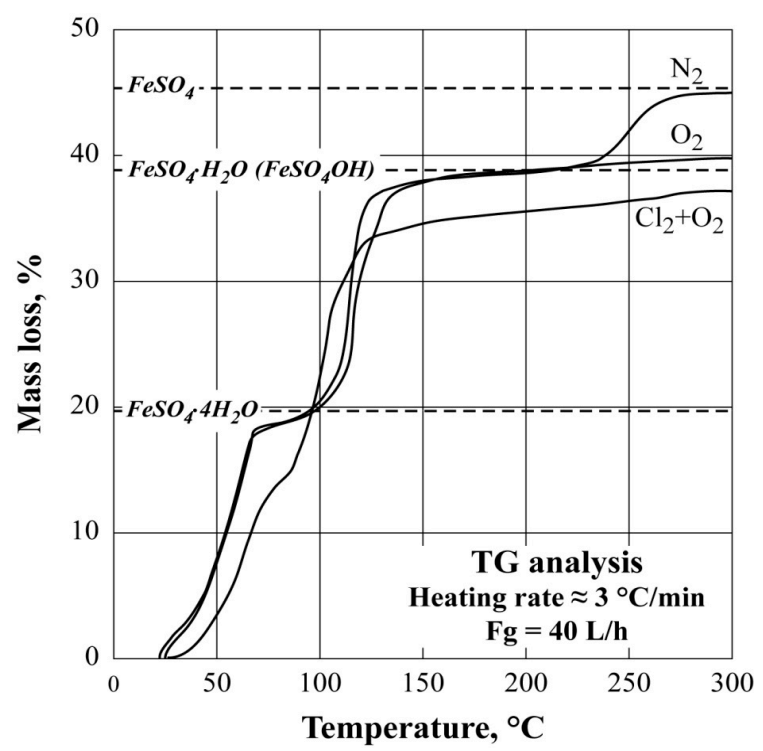

Figure 2. Thermogravimetric (TG) analysis of a $\mathrm{FeSO}_{4} \cdot 7 \mathrm{H}_{2} \mathrm{O}$ sample under different atmospheres.

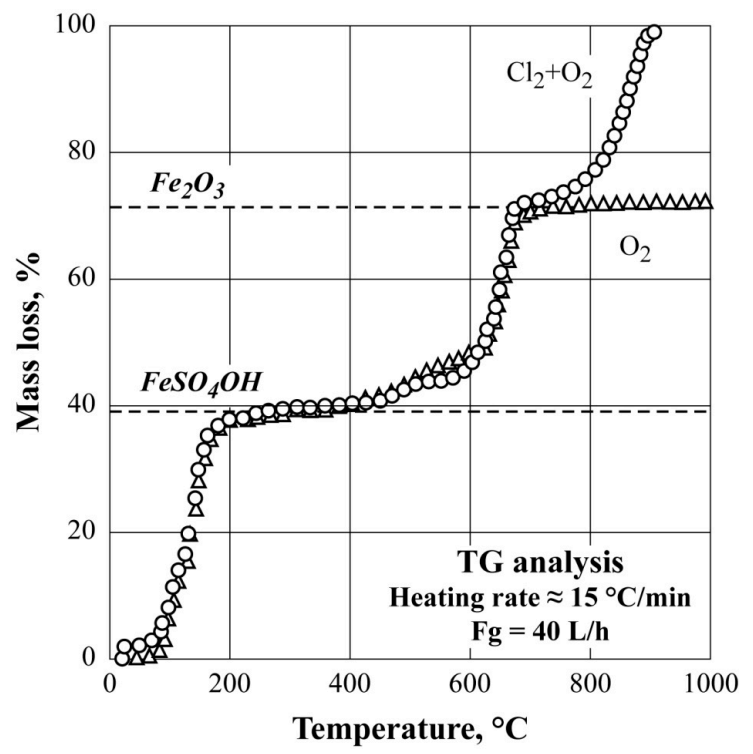

Figure 3. TG analysis of a $\mathrm{FeSO}_{4} \cdot 7 \mathrm{H}_{2} \mathrm{O}$ sample in $\mathrm{O}_{2}$ and $\mathrm{Cl}_{2}+\mathrm{O}_{2}$ atmospheres.

Table 2. Endothermic peaks $\left({ }^{\circ} \mathrm{C}\right)$ revealed by differential thermal (DT) analysis for the treatment of $\mathrm{FeSO}_{4} \cdot 7 \mathrm{H}_{2} \mathrm{O}$ under nitrogen at various heating rates.

\begin{tabular}{ccccccc}
\hline \multicolumn{2}{l}{ Heating Rate, ${ }^{\circ} \mathbf{C}$ /min } & & \multicolumn{2}{l}{ Possible Reaction Steps } \\
\cline { 1 - 3 } $\mathbf{2 . 5}$ & $\mathbf{5 . 0}$ & $\mathbf{1 0 . 0}$ & & & \\
\hline 70 & 80 & 98 & & $\mathrm{FeSO}_{4} \cdot 7 \mathrm{H}_{2} \mathrm{O}$ & $\rightarrow$ & $\mathrm{FeSO}_{4} \cdot 4 \mathrm{H}_{2} \mathrm{O}$ \\
86 & 133 & 159 & $\mathrm{FeSO}_{4} \cdot 4 \mathrm{H}_{2} \mathrm{O}$ & $\rightarrow$ & $\mathrm{FeSO}_{4} \cdot \mathrm{H}_{2} \mathrm{O}$ \\
227 & 250 & 283 & $\mathrm{FeSO}_{4} \cdot \mathrm{H}_{2} \mathrm{O}$ & $\rightarrow$ & $\mathrm{FeSO}_{4}$ \\
653 & 687 & 716 & & $\mathrm{FeSO}_{4}$ & $\rightarrow$ & $\mathrm{Fe}_{2} \mathrm{O}_{3}$ \\
\hline
\end{tabular}

\subsection{Nonisothermal TG Analysis of $\mathrm{FeSO}_{4} \cdot \mathrm{H}_{2} \mathrm{O}$ under Nitrogen}

Nonisothermal TG tests up to $1000{ }^{\circ} \mathrm{C}$ in nitrogen were performed for both IND and LAB samples. The furnace heating rates were fixed at 2.5 and $20.0^{\circ} \mathrm{C} / \mathrm{min}$, and the data is plotted as the evolution of the $\% \mathrm{ML}$ as a function of temperature. Figure 4 shows the results for the IND sample. The $\% \mathrm{ML}$ obtained between 200 and $400{ }^{\circ} \mathrm{C}$ corresponds to the dehydration of $\mathrm{FeSO}_{4} \cdot \mathrm{H}_{2} \mathrm{O}$ 
into $\mathrm{FeSO}_{4}$. The theoretical \% ML for the dehydration of iron sulfate monohydrate into iron sulfate (dashed horizontal line) matches well with the experimental \% ML of this sample. As shown in Figure 5, the behavior of the LAB sample seems to be somewhat different when compared with the IND sample. Only $7 \%$ ML was observed at temperatures less than or equal to $400{ }^{\circ} \mathrm{C}$. This could be attributed to the dehydration of $\mathrm{FeSO}_{4} \cdot \mathrm{H}_{2} \mathrm{O}$ into $\mathrm{FeSO}_{4}$. The continuous mass loss of the LAB sample between 400 and $550{ }^{\circ} \mathrm{C}$ was probably due to the transformation of $\mathrm{FeSO}_{4} \cdot \mathrm{OH}$ into ferric oxysulfate $\left(\mathrm{Fe}_{2} \mathrm{O}\left(\mathrm{SO}_{4}\right)_{2}\right)$. The decomposition of iron sulfates producing ferric oxides takes place at temperatures higher than $575{ }^{\circ} \mathrm{C}$, and the curve shapes for both samples seem to be similar. The XRD analysis of the decomposition product showed the presence of $\mathrm{Fe}_{2} \mathrm{O}_{3}$ in the main crystallized phase.

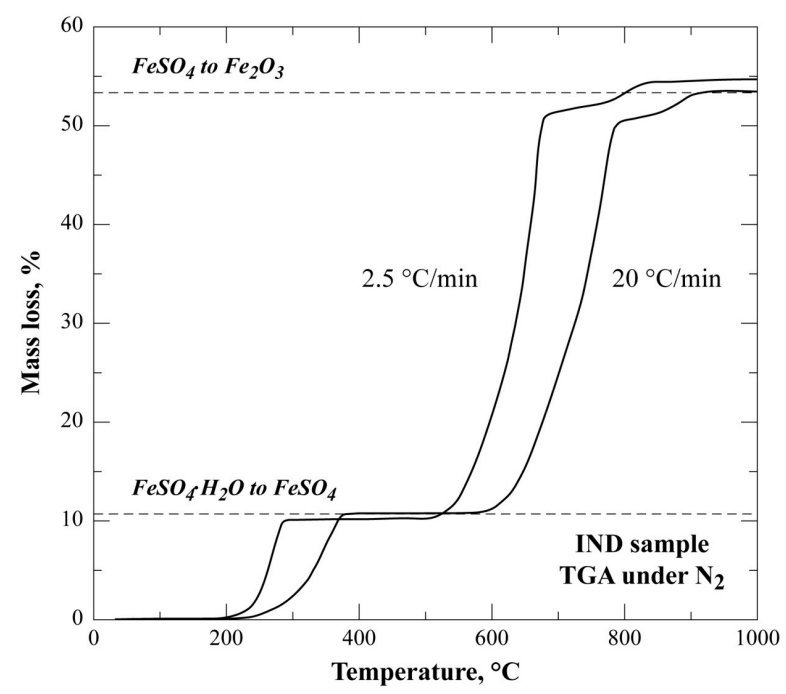

Figure 4. TG analysis in $\mathrm{N}_{2}$ of the IND sample.

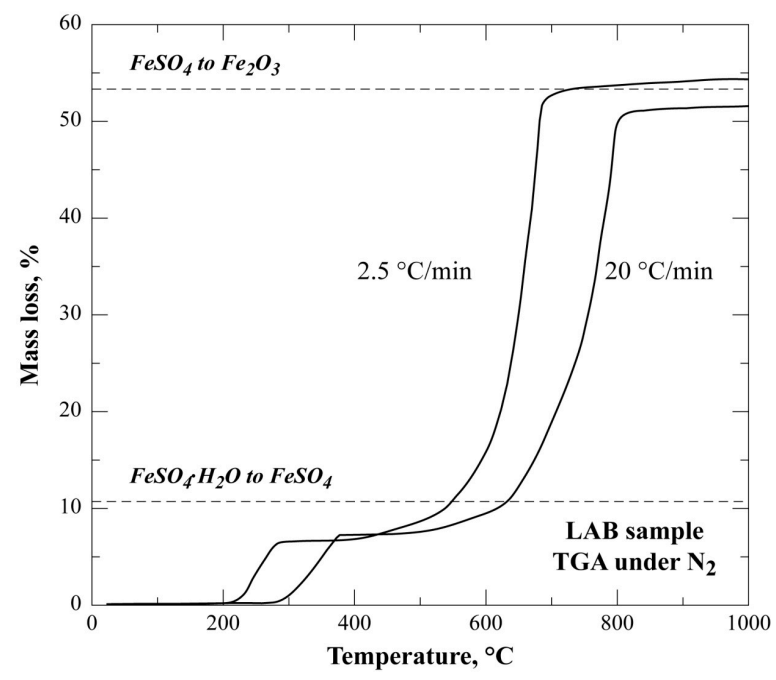

Figure 5. TG analysis in $\mathrm{N}_{2}$ of the LAB sample.

Based on these TG results, the decomposition kinetics in nitrogen atmosphere of both iron sulfate samples into iron oxide were studied under isothermal conditions at temperatures higher than or equal to $500{ }^{\circ} \mathrm{C}$.

\subsection{Isothermal Decomposition of $\mathrm{FeSO}_{4} \cdot \mathrm{H}_{2} \mathrm{O}$ Samples}

This decomposition process was tested at low temperatures (between 500 and $575^{\circ} \mathrm{C}$ ) to minimize the iron sulfate decomposition during the nonisothermal temperature rise. Thus, the initial temperature increased linearly (heating rate $=5.0^{\circ} \mathrm{C} / \mathrm{min}$ ) up to a fixed value, then the temperature remained 
constant, and the decomposition extent followed a function of time. A typical example of experimental conditions and results is given in Figure 6. The temperature profile was programmed to increase up to $560{ }^{\circ} \mathrm{C}$; from this point, the decomposition rate (\% ML vs. time) was measured at $560{ }^{\circ} \mathrm{C}$. It should be noted that the $\% \mathrm{ML}$ observed during nonisothermal test ( $\leq 12 \% \mathrm{ML})$ corresponds to the dehydration step of $\mathrm{FeSO}_{4} \cdot \mathrm{H}_{2} \mathrm{O}$ to $\mathrm{FeSO}_{4}$.

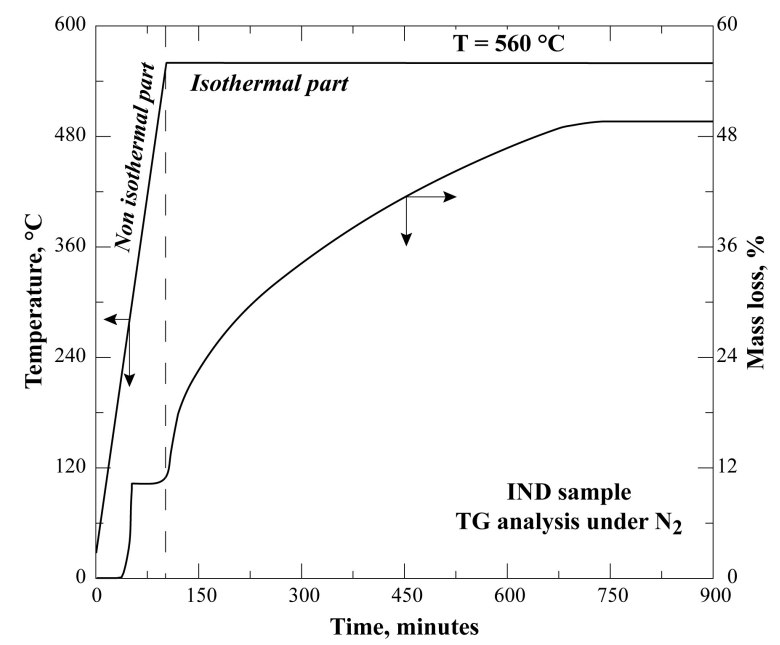

Figure 6. Typical example of TG analysis results of iron sulfate decomposition.

The behavior of both IND and LAB samples under isothermal treatment was monitored in order to check the eventual impact of Fe(III) sulfate on the transformation kinetics. The results obtained from the treatment of the IND sample in nitrogen are represented in Figure 7 . About $50 \mathrm{~h}$ were necessary for the half decomposition of iron sulfate at $500{ }^{\circ} \mathrm{C}$, while full decomposition was achieved in less than $7 \mathrm{~h}$ at $575{ }^{\circ} \mathrm{C}$. This result seems to indicate that the decomposition process depends highly on the temperature.

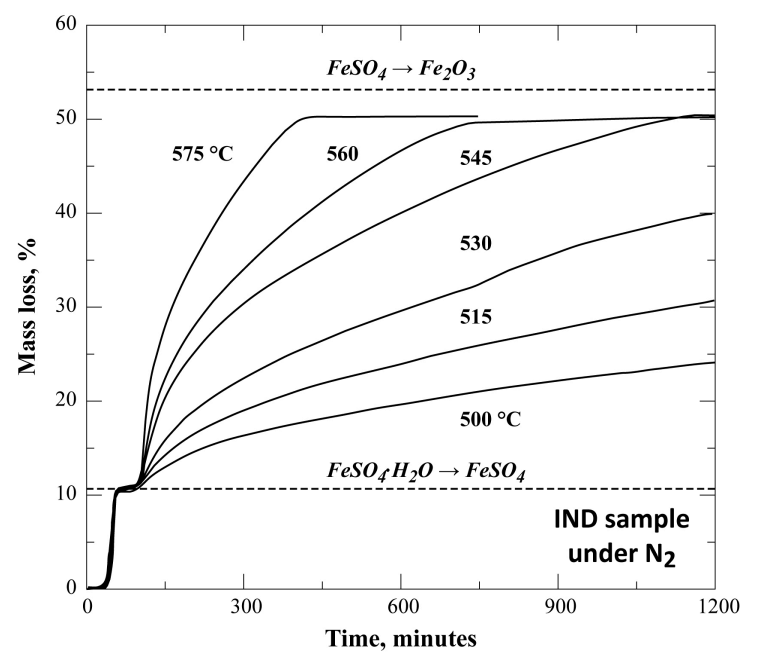

Figure 7. Evolution of the percent mass loss (\% ML) as a function of time during the isothermal treatment of an industrial sample under nitrogen between 500 and $575{ }^{\circ} \mathrm{C}$.

Experimental results corresponding to the treatment of LAB sample are illustrated in Figure 8 as $\%$ ML versus time for temperatures ranging from 500 to $575^{\circ} \mathrm{C}$. The isothermal part ( $\geq 12 \% \mathrm{ML}$ ) of the curves has a similar shape to that observed in the IND sample. When the temperature was increased from 500 to $575^{\circ} \mathrm{C}$, the initial decomposition rate was multiplied by a factor of about 26 . 


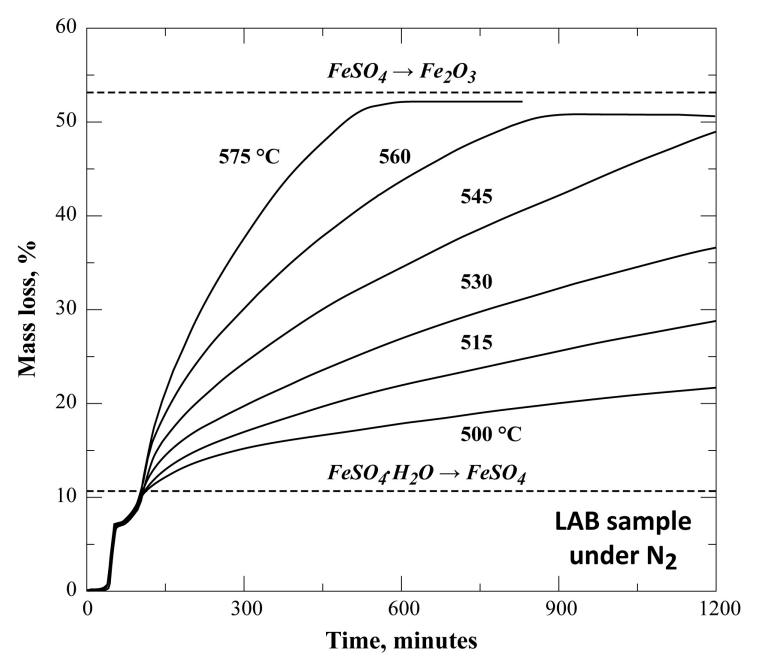

Figure 8. Evolution of the \% ML as a function of time during the isothermal treatment of a laboratory sample under nitrogen between 500 and $575^{\circ} \mathrm{C}$.

Arrhenius diagrams for both samples were established in order to evaluate the temperature effect on the initial decomposition rate of iron sulfates. The mean decomposition rate was calculated by linearization of the isothermal data corresponding to $12.5 \% \leq \mathrm{ML} \leq 22.5 \%$. As shown in Figure 9, the decomposition rate of the IND sample was higher than that for the LAB sample over the complete range of temperatures. The values of the apparent activation energy for the treatment of industrial and laboratory sample were about 262 and $238 \mathrm{~kJ} / \mathrm{mol}$, respectively, showing the strong effect of temperature on the decomposition process of iron sulfate between 500 and $575{ }^{\circ} \mathrm{C}$. A similar value of apparent activation energy (average value of $244 \mathrm{~kJ} / \mathrm{mol}$ ) was obtained in the work reported by Huang et al. [4].

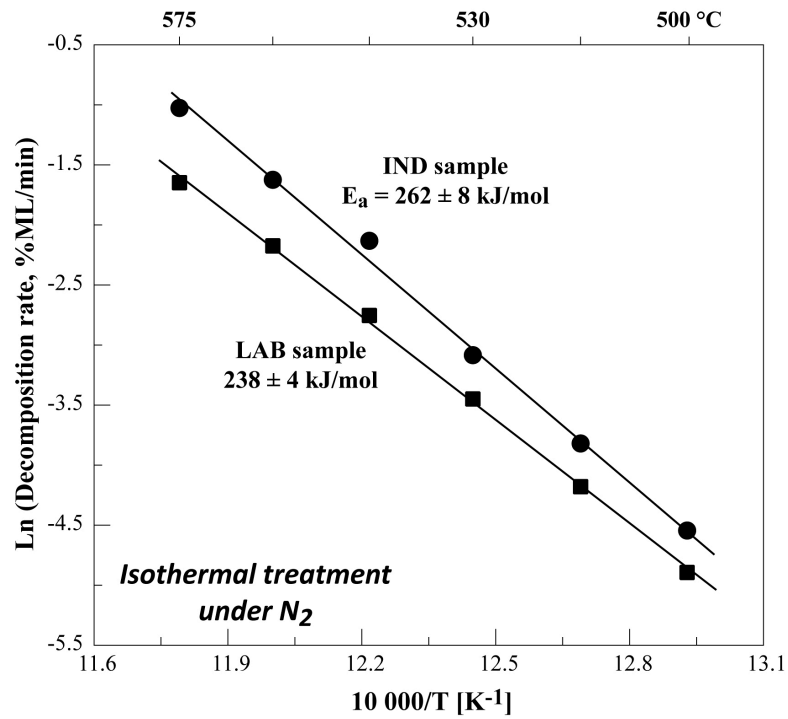

Figure 9. Arrhenius diagram for the decomposition of the iron sulfate samples under nitrogen for temperatures ranging from 500 to $575^{\circ} \mathrm{C}$.

The reaction product generated by the thermal treatment of iron sulfates was mainly composed of pure iron (III) oxide. Such a material, in powder state, must be agglomerated before use for pig iron production and/or for more valuable end uses, such as high-grade pigments for cosmetics. 


\section{Conclusions}

The dehydration of iron sulfate heptahydrate $\left(\mathrm{FeSO}_{4} \cdot 7 \mathrm{H}_{2} \mathrm{O}\right)$ in nitrogen occurred through at least three steps: $\mathrm{FeSO}_{4} \cdot 7 \mathrm{H}_{2} \mathrm{O} \rightarrow \mathrm{FeSO}_{4} \cdot 4 \mathrm{H}_{2} \mathrm{O} \rightarrow \mathrm{FeSO}_{4} \cdot \mathrm{H}_{2} \mathrm{O} \rightarrow \mathrm{FeSO}_{4}$. Complete dehydration of $\mathrm{FeSO}_{4} \cdot 7 \mathrm{H}_{2} \mathrm{O}$ occurred at a temperature lower than $300{ }^{\circ} \mathrm{C}$. The treatment of $\mathrm{FeSO}_{4} \cdot 7 \mathrm{H}_{2} \mathrm{O}$ under oxidizing atmosphere led to the formation of $\mathrm{Fe}^{\mathrm{III}} \mathrm{SO}_{4} \cdot \mathrm{OH}$ as a final stable product at $300{ }^{\circ} \mathrm{C}$.

The decomposition of iron sulfates $\left(\mathrm{FeSO}_{4}\right.$ and $\left.\mathrm{Fe}^{\mathrm{III}} \mathrm{SO}_{4} \cdot \mathrm{OH}\right)$ generating ferric oxide, in nonisothermal conditions, started at $\mathrm{T}>500^{\circ} \mathrm{C}$, and the final temperature of their full decomposition depended on the heating rate in the furnace.

The isothermal decomposition of selected iron sulfate samples was strongly affected by temperature as it proceeded with a value of apparent activation energy of $250 \mathrm{~kJ} / \mathrm{mol}$ between 500 and $575{ }^{\circ} \mathrm{C}$. The obtained iron oxide could be used as an appropriate raw material in the ferrous metallurgy sector and/or for more noble end uses.

Author Contributions: Conceptualization, N.K., N.-E.M. and E.O.; Formal analysis, N.-E.M. and E.O.; Investigation, N.K., E.O. and F.D.; Visualization, S.S. and F.D.; Resources, F.D. and J.Y.; Writing一original draft, N.K., E.O., S.S. and E.A.; Writing-review and editing, N.K., E.O, E.A. and J.Y.

Funding: A part of this work was performed in the frame of contract No. BRPR-CT97-0392 of the European Union. Another part of this development work was supported by the French National Research Agency through the program "Investissements d'avenir" with the reference ANR-10-LABX-21-01/LABEX RESSOURCES21.

Conflicts of Interest: The authors declare no conflict of interest.

\section{References}

1. Kanari, N. Contribution to Chlorine Chemistry and its Applications: Synthesis of Alkali Ferrates (VI). A Study of the Kinetics of Chlorine-Solid Reactions; Defense of the Habilitation Diploma (HDR), Institut National Polytechnique de Lorraine: Nancy, France, 2000.

2. Zhang, W.; Zhu, Z.; Cheng, C.Y. A literature review of titanium metallurgical processes. Hydrometallurgy 2011, 108, 177-188. [CrossRef]

3. Kanari, N.; Filippova, I.; Diot, F.; Mochón, J.; Ruiz-Bustinza, I.; Allain, E.; Yvon, J. Utilization of a waste from titanium oxide industry for the synthesis of sodium ferrate by gas-solid reactions. Thermochim. Acta 2014, 575, 219-225. [CrossRef]

4. Huang, P.; Deng, S.; Zhang, Z.; Wang, X.; Chen, X.; Yang, X.; Yang, L. A sustainable process to utilize ferrous sulfate waste from titanium oxide industry by reductive decomposition reaction with pyrite. Thermochim. Acta 2015, 620, 18-27. [CrossRef]

5. Kanari, N.; Ostrosi, O.; Ninane, N.; Neveux, N.; Evrard, O. Synthesizing alkali ferrates using a waste as a raw material. JOM 2005, 57, 39-42. [CrossRef]

6. Kanari, N. Method of Producing Ferrates (VI). French Patent n ${ }^{\circ} 2905$ 609, 14 March 2008.

7. Wei, Y.-L.; Wang, Y.-S.; Liu, C.-H. Preparation of potassium ferrate from spent steel pickling liquid. Metals 2015, 5, 1770-1787. [CrossRef]

8. Pineau, A.; Kanari, N.; Gaballah, I. Kinetics of reduction of iron oxides by $\mathrm{H}_{2}$ : Part I: Low temperature reduction of hematite. Thermochim. Acta 2006, 447, 89-100. [CrossRef]

9. Jozwiak, W.K.; Kaczmarek, E.; Maniecki, T.P.; Ignaczak, W.; Maniukiewicz, W. Reduction behavior of iron oxides in hydrogen and carbon monoxide atmospheres. Appl. Catal. A 2007, 326, 17-27. [CrossRef]

10. Pineau, A.; Kanari, N.; Gaballah, I. Kinetics of reduction of iron oxides by $\mathrm{H}_{2}$ : Part II. Low temperature reduction of magnetite. Thermochim. Acta 2007, 456, 75-88. [CrossRef]

11. Tang, J.; Chu, M.S.; Ying, Z.W.; Li, F.; Feng, C.; Liu, Z.G. Non-isothermal gas-based direct reduction behavior of high chromium vanadium-titanium magnetite pellets and the melting separation of metallized pellets. Metals 2017, 7, 153. [CrossRef]

12. Cao, Y.; Zhang, Y.; Sun, T. Dephosphorization behavior of high-phosphorus oolitic hematite-solid waste containing carbon briquettes during the process of direct reduction-magnetic separation. Metals 2018, 8, 897. [CrossRef]

13. Oh, J.; Noh, D. The reduction kinetics of hematite particles in $\mathrm{H}_{2}$ and $\mathrm{CO}$ atmospheres. Fuel 2017, 196, 144-153. [CrossRef] 
14. Chen, Z.; Dang, J.; Hu, X.; Yan, H. Reduction kinetics of hematite powder in hydrogen atmosphere at moderate temperatures. Metals 2018, 8, 751. [CrossRef]

15. Tang, H.; Yun, Z.; Fu, X.; Du, S. Modeling and experimental study of ore-carbon briquette reduction under $\mathrm{CO}-\mathrm{CO}_{2}$ atmosphere. Metals 2018, 8, 205. [CrossRef]

16. Fukushima, J.; Takizawa, H. In situ spectroscopic analysis of the carbothermal reduction process of iron oxides during microwave irradiation. Metals 2018, 8, 49. [CrossRef]

17. Kanari, N.; Mishra, D.; Filippov, L.; Diot, F.; Mochón, J.; Allain, E. Kinetics of hematite chlorination with $\mathrm{Cl}_{2}$ and $\mathrm{Cl}_{2}+\mathrm{O}_{2}$ : Part I. Chlorination with $\mathrm{Cl}_{2}$. Thermochim. Acta 2010, 497, 52-59. [CrossRef]

18. Kanari, N.; Mishra, D.; Filippov, L.; Diot, F.; Mochón, J.; Allain, E. Kinetics of hematite chlorination with $\mathrm{Cl}_{2}$ and $\mathrm{Cl}_{2}+\mathrm{O}_{2}$. Part II. Chlorination with $\mathrm{Cl}_{2}+\mathrm{O}_{2}$. Thermochim. Acta 2010, 506, 34-40. [CrossRef]

(C) 2018 by the authors. Licensee MDPI, Basel, Switzerland. This article is an open access article distributed under the terms and conditions of the Creative Commons Attribution (CC BY) license (http:/ / creativecommons.org/licenses/by/4.0/). 